\title{
Academic performance in water treatment subjects: Comparison between Chemical Engineering and Environmental Sciences
}

\section{Rendimiento académico en asignaturas de tratamiento de aguas: Comparación entre Ingeniería Química y Ciencias Ambientales}

\author{
J.C. Leyva-Díaz \\ University of Granada. Granada, Spain \\ jcleyva@ugr.es \\ R. Álvarez-Arroyo \\ University of Granada. Granada, Spain \\ rocioaarroyo@ugr.es
}

\begin{abstract}
As a result of the guidelines from the European Higher Education Area (EHEA) of an education system based on learning more than teaching, this study emerges with the objective of assessing the performance of students in theoretical and practice learning in Degree in Chemical Engineering and Degree in Environmental Sciences. The study was carried out on 208 total students and by selecting two common laboratory practices and theoretical classes in both degrees. The research concluded the existence of statistically significant differences between the students of both degrees in all aspects evaluated, including both the theoretical and practice learning. In this regard, the students of the Degree in Chemical Engineering showed a success rate which doubled the one got by the students of the Degree in Environmental Sciences, with a higher valuation in the academic performance by the students of the Degree in Chemical Engineering. Generally, the students obtained better results in the evaluation of the practice teaching than in the theoretical one, which strengthens the concept of the EHEA consisting of introducing a teaching more applied and focused on the obtaining of competences with future application in the job market.
\end{abstract}

Key words

EHEA, academic performance, learning, Chemical Engineering, Environmental Sciences.

\footnotetext{
Resumen

Como resultado de las directrices del Espacio Europeo de Educación Superior (EEES) de un sistema educativo basado en el aprendizaje más que en la enseñanza, este estudio surge con el objetivo de evaluar el rendimiento de los estudiantes en el aprendizaje teórico y práctico en Grado en Ingeniería Química y Grado en Ciencias Ambientales. El estudio se llevó a cabo con 208 estudiantes en total y seleccionando dos prácticas comunes de laboratorio y clases teóricas en ambos grados. La investigación concluyó la existencia de diferencias estadísticamente significativas entre los estudiantes de ambos grados en todos los aspectos evaluados, incluyendo tanto el aprendizaje teórico como práctico. En este sentido, los estudiantes del Grado en Ingeniería Química mostraron una tasa de éxito que duplicaba la obtenida por los estudiantes del Grado en Ciencias Ambientales, con una mayor valoración en el rendimiento académico por parte de los estudiantes del Grado en Ingeniería Química. En general, los estudiantes obtuvieron mejores resultados en la evaluación de la práctica docente que en la teórica, lo que refuerza el concepto de EEES consistente en introducir una enseñanza más aplicada y enfocada en la obtención de competencias con futura aplicación en el mercado laboral.

Palabras clave

EEES, rendimiento académico, aprendizaje, Ingeniería Química, Ciencias Ambientales.
} 


\section{Introduction}

The Sorbonne Declaration in 1998 supposed the first step to form the European Higher Education Area (EHEA), which emerged with the aim of getting a European convergence in the direction of a higher compatibility and comparability of the higher education systems (Ministros Europeos de Educación, 1999). In Spain, EHEA was introduced in 2010 through the known Bologna Process, which has set out an important challenge for the Spanish education, consisting of changing a traditional education system based on the teaching to a new system based on the learning (Ministerio de Educación y Ciencia, 2007; Bayón et al., 2013). This challenge is higher in technical degrees, where there is a strong conservationism concerning the traditional teaching (Molina Álvarez, 1999).

Among the different objectives of the new European framework, it should be noted the "lifelong learning" of the student and/or the promotion of the international mobility to other higher education centers. But the legislation also highlights the fact that the training must let graduates access to the labor market with higher employability guarantee (European Ministers Responsible for Higher Education, 2009). In light of this, one of the objectives of the European universities is to favor the labor insertion of their graduates through a training based on the acquisition of competences that lets them adapt to the requirements of the labor market as the companies value and assess to their workers increasingly through these competences (McClelland, 1973). This aspect must be considered as, according to a study of labor insertion present in the White Book of the Bachelor Degree in Chemical Engineering (CE) (ANECA, 2005a), only 20\% of these graduates performed a work totally related to their training in the period 20002004. Regarding the Degree in Environmental Sciences (ES), there is also a high percentage of graduates $(35 \%)$ that are unemployed or widening studies (ANECA, $2005 \mathrm{~b}$ ). Therefore, the new plans of study of the different degrees have been prepared to accomplish this new perspective of acquisition of competences by the students, that the EHEA proposes, without excluding the traditional methods of training based on contents and school hours (Ministerio de Educación y Ciencia, 2007).

As a consequence of this changing process in the education field, EHEA constitutes an opportunity to adapt to the new situations (González \& Wagenaar, 2008; FernándezSainz et al., 2016). In light of this, Bologna process introduced reforms to improve the standard of the teaching and learning processes and these changes must be confirmed by results in order to check if the performance of students has improved (Herrero and Algarrada, 2010). According to Marcerano and Navarro (2007), it is necessary to quantify the outcomes obtained by students through a formal education based in the Bologna process.

The evaluation of students is the process by which their progress is determined during a period of teaching and learning (López-Pastor et al., 2013). The learning outcomes indicate what students are able to know, understand and perform (Aamodt \& Hovdhaugen, 2008). This process must provide enough information to take decisions and to make judgements at the end of the assessment process (Tembrink, 2006). In the educative context, this information constitutes a combination of knowledge, skills and attitudes that describe the results concerning the learning of an education program and these outcomes must be linked to the demands from the labor market (Bergan, 2007; Rico et al., 2013). 
According to Aamodt et al. (2007), the results obtained from the learning process must constitute a statement of what students are expected to learn (learning objectives) and a measurement of what students have actually learnt during their studies. This will affect both the teaching process and the students' learning assessment in higher education (Aamodt \& Hovdhaugen, 2008). In light of this, the assessment also directs the students' learning (by continuous evaluation), as well as measuring the learning outcomes (by summative evaluation), showing a clear effect on teaching and learning (Havnes, 2004). Thus, the assessment methods and criteria must be related to the objectives of the students' learning, having decided previously the aspects that have to be evaluated (Hager et al., 1994).

There are few works dealing with the evaluation of the academic performance due to the implementation of this teaching methodology (Mulder et al., 2009), residing in this aspect the main contribution of the present study. Based on these ideas, this study intends to evaluate the performance obtained by the students through the theoretical and practical learning applied to the Degree in CE and Degree in ES.

\section{Methodology}

\subsection{Participants}

In order to have as many participants as possible, the study was carried out in two academic courses (2013/2014 and 2014/2015). In this research, a total of 208 participants at University of Granada were involved, who belonged to the scientifictechnical field: 104 students of Degree in CE and 104 students of Degree in ES. Given that the aim of this study was to compare the academic performance in both groups, two subjects with similar contents regarding water treatment technologies were selected from these degrees.

Concerning the Degree in CE, the subject selected was Environmental Engineering, which is an obligatory subject. It has 6 credits ECTS and is taught in the seventh semester of the fourth course of this degree. Regarding the Degree in ES, the subject selected was Water Treatment and Technology, which is also an obligatory subject. It has 6 credits ECTS and is taught in the fifth semester of the third course. Both subjects have identical laboratory practices, called "Characterization of municipal wastewater" (P1) and "Settling test" (P2).

The theoretical and practical teaching was given by the same professors and the contents were identical for both subjects in order to compare the evolution of the students in the present case of study. Consequently, the students learnt the same theoretical contents before the monitoring and laboratory practices, which ensured a similar formation in the subjects.

\subsection{Procedure}

According to the guidelines from the EHEA, and considering the plans of study of Degree in CE and Degree in ES (ANECA, 2000a; ANECA, 2000b), the subjects of this study were designed to implement the learning and not only the teaching. Thus, the teaching methodology followed for the academic courses analyzed in this study was formed by three methodological typologies that are developed as follows. 
One of the methodologies is called master lecture. Despite this method has a traditional nature based on the teaching, this is necessary to introduce the theoretical concepts and to develop the contents proposed in the subjects. Master lecture must be carried out in a motivating and participatory environment by the professors and students, respectively.

The second type of methodology used is the monitoring, which consists of the resolution of different exercises, tests and problems by the students to apply the theoretical knowledge that has been acquired in the master lecture. This methodology is focused on assessing the teaching-learning process continuously in order to direct and/or correct it depending on the difficulties found in the students.

Finally, the laboratory practice teaching is based on the experimental application of the knowledge and skills acquired through the master lecture and monitoring of students. In order to carry out the laboratory practices, the students previously receive an independent learning guide to facilitate the understanding of the practice and to get that students are capable of doing the practice independently. It should be noted that laboratory work is carried out in groups reduced of two students with the aim of encouraging the teamwork.

In the laboratory practice called "Characterization of municipal wastewater", the students must learn to determine the physicochemical parameters: chemical oxygen demand, biochemical oxygen demand on the fifth day and suspended solids, which are previously explained in the master lecture, according to the analytical methods described in the independent learning guide that is provided to the students. In light of this, wastewater samples taken from different zones of a wastewater treatment plant are supplied to the students. The students must apply the knowledge acquired through master lecture, learn to manipulate laboratory instruments, do the calculations necessary to assess each parameter, manage all the information, determine the efficiency of the wastewater treatment plant, synthesize the information and carry out the decision making according to the applicable legislation about wastewater.

In the laboratory practice named "Settling test", the students must apply the concept of settling and distinguish the components of a settler at pilot scale. The theoretical basis of the settling process was previously studied in the master lecture and monitoring activities. The students have to study the independent learning guide before attending the practice session to carry out the analysis of suspended solids for water samples taken at different heights of the settler and different times. Each group analyzes the evolution of suspended solids for each height studied. The students must fit mathematical functions to the evolution of suspended solids through the application of mathematical tools and computer programs of data analysis. Subsequently, they determine the isoconcentration curves that enable the estimation of the experimental settling rates. Finally, a real case of study is considered concerning the design of a settler, in which the students must apply mass balances with the aim of assessing the settling area, hydraulic retention time and upward settling rate, which are design and operation parameters of a settler. In order to carry out these calculations, the student must use the values of settling rate evaluated experimentally. Thus, the students have to develop the ability of analysis and problem resolution, promoting the independent learning and critical reasoning to decide the optimal settling area.

Each of the teaching methodologies previously described was evaluated through the system that was considered more suitable, as indicated next, to evaluate and compare objectively the performance of all the students participating in this study. 
The master lecture was evaluated through a final written exam due to its traditional character. This exam contained theoretical questions and numerical problems. Regarding the monitoring, each student had to hand in exercises resolved and understanding tests of theoretical concepts as continuous evaluation during the academic course. Each of these activities was evaluated by the professor. Despite the fact that the laboratory practice was carried out in groups of two students, each one had to hand in a report including all the results and conclusions obtained in the practice session, which were requested in the independent learning guide of both laboratory practices. This report was evaluated and graded by the professor.

The final grade of each student was the weighted sum of the grades of the written exam (70\%), monitoring activities (15\%) and laboratory practices $(15 \%)$.

The competences, which must acquire the students of each degree, are included in the corresponding plan of study, following the general competences determined in the disposition that regulates the professional competences and the recommendations of the White Book of the respective degree. In this regard, each degree establishes general, cross and specific competences. The specific competences refer to the technical abilities that are required to carry out a work or activity related to the qualification (Solanes et al., 2008). The cross competences consist of personal qualities of attitudinal, appreciatory, social or cognitive nature that are necessary to apply the technical skills to different situations, although they are not directly related to the technical knowledge (Bridgstock, 2009; Rico et al., 2013). The cross competences include personal, interpersonal, intellectual, organizational and business competences, enabling the adaptation to different professional worlds and the integration in the social life (Ortega Navas, 2010).

Table 1 shows the different competences that must be achieved by the students through each of the three methodologies analyzed, master lecture, monitoring and laboratory practice for the subjects Environmental Engineering belonging to Degree in CE and Water Treatment and Technology corresponding to Degree in ES, highlighting the similarity of competences concerning water treatment technologies.

Table 1. Competences of the subject of Environmental Engineering corresponding to the Degree in CE and the subject of Water Treatment and Technology belonging to the Degree in ES. 


\section{Environmental Engineering (Degree in CE)}

General competences

CG2

Application of Chemical Engineering knowledge to the professional world, including the ability of solving issues and problems with initiative, taking decisions, creativity and critical reasoning

CG4 Transmission of information, ideas, problems and solutions to a specialized or not audience concerning Chemical Engineering

CG5 Development of learning abilities that are necessary to carry out subsequent specialized studies with a high autonomy degree

\begin{tabular}{|c|c|}
\hline \multicolumn{2}{|r|}{ Cross competences } \\
\hline CI1 & Analysis and synthesis ability \\
\hline $\mathrm{CI} 3$ & Oral and written communication in the own language \\
\hline $\mathrm{CI} 4$ & Management ability of information \\
\hline CI5 & Resolution of problems \\
\hline CS4 & Ability for independent working \\
\hline CS9 & Sensitivity regarding environmental issues \\
\hline \multicolumn{2}{|r|}{ Specific competences } \\
\hline CR6 & $\begin{array}{l}\text { Basic knowledge and application of environmental technologies and } \\
\text { sustainability }\end{array}$ \\
\hline \multicolumn{2}{|r|}{ Water Treatment and Technology (Degree in ES) } \\
\hline \multicolumn{2}{|r|}{ General competences } \\
\hline CT1 & $\begin{array}{l}\text { Understanding of the scientific method. Ability of analysis, synthesis and } \\
\text { problem resolution }\end{array}$ \\
\hline $\mathrm{CT} 2$ & Critical reasoning and independent learning \\
\hline CT3 & Computer knowledge corresponding to the field of study \\
\hline CT4 & Organization and planning ability \\
\hline CT5 & Oral and written communication \\
\hline CT6 & Management ability of information \\
\hline CT7 & Teamwork \\
\hline CT8 & Creativity \\
\hline \multicolumn{2}{|r|}{ Specific competences } \\
\hline CE1 & Use of mathematical tools to solve problems concerning the environment \\
\hline CE3 & $\begin{array}{l}\text { Knowledge and application of terminology and units of measure to the physical } \\
\text { processes }\end{array}$ \\
\hline CE5 & $\begin{array}{l}\text { Acquisition, development and practice of skills which are necessary for the } \\
\text { laboratory work and the basic instrumentation in physics, chemistry and biology }\end{array}$ \\
\hline CE12 & $\begin{array}{l}\text { Design of sampling, data processing, and analysis of statistical results and } \\
\text { programs and databases }\end{array}$ \\
\hline CE14 & $\begin{array}{l}\text { Knowledge and interpretation of the basic environmental legislation and } \\
\text { administration regarding soil, water, atmosphere, natural sources, conservation, } \\
\text { urban planning and zoning management }\end{array}$ \\
\hline CE20 & $\begin{array}{l}\text { Ability of carrying out mass and energy balances applied to all kind of } \\
\text { processes and systems }\end{array}$ \\
\hline CE22 & Management and treatment of supply water, irrigation water and wastewater \\
\hline CE31 & Planning and development of clean technologies and renewable energies \\
\hline
\end{tabular}

CE Chemical Engineering, ES Environmental Sciences 


\subsection{Data analysis}

The software IBM $^{\circledR}$ SPSS $^{\circledR}$ Statistics v22.0 for Windows was utilized to determine statistically significant differences between the grades obtained by the students of Degree in CE and Degree in ES in each of the methodologies evaluated in this study. The data obtained concerning the grades of the laboratory practices, written exam and monitoring activities depending on the degree were analyzed by ANOVA under the null hypothesis of independence and homogeneity with a significance level of 5\% ( $\alpha=0.05)$.

In order to obtain the effect size of ANOVA, partial eta squared was used. An effect size of 0.0099 was considered small, 0.0588 was interpreted as medium and 0.1379 as a large one (Richardson, 2011).

\section{Results and Discussion}

Having collected all the necessary information to accomplish the aims of this study, an analysis of all the grades obtained by the students was carried out according to the evaluation system indicated previously.

The results obtained by the students belonging to Degree in CE and Degree in ES in each of the three modules that have been evaluated can be observed in Figure 1.
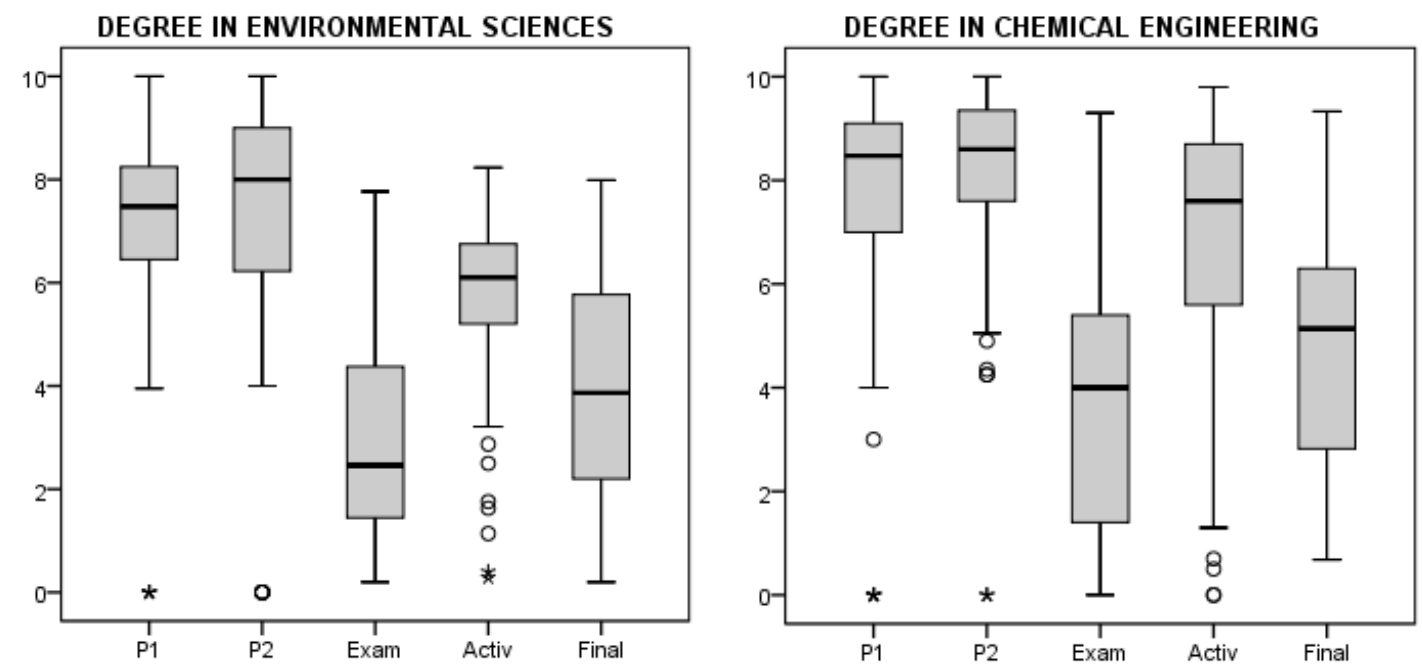

Figure 1. Grades obtained by the students in the laboratory practice, exam and monitoring depending on the degree. P1 (Laboratory practice "Characterization of municipal wastewater"), P2 (Laboratory practice "Settling test").

Furthermore, Table 2 shows these results numerically, as well as descriptive statistics of the analysis of variances (ANOVA). 
Table 2. Average of exam, monitoring and laboratory practice grades of CE and ES students, success rate of students in each evaluation system and comparison of both degrees by ANOVA.

\begin{tabular}{|c|c|c|c|c|c|c|c|}
\hline \multirow{2}{*}{ Evaluation system } & \multicolumn{2}{|c|}{$\mathbf{M} \pm$ SD } & \multirow{2}{*}{$F$} & \multirow{2}{*}{$p$} & \multirow{2}{*}{$\eta 2$} & \multicolumn{2}{|c|}{ Success rate $(\%)^{a}$} \\
\hline & ESD & CED & & & & ESD & CED \\
\hline Exam & $2.93 \pm 1.90$ & $3.44 \pm 2.53$ & 3.188 & .075 & .019 & 14.79 & 29.20 \\
\hline Monitoring & $5.54 \pm 1.65$ & $6.58 \pm 2.66$ & 15.517 & $.000 *$ & .056 & 76.06 & 75.91 \\
\hline Laboratory practice P1 & $7.00 \pm 2.03$ & $7.81 \pm 2.04$ & 10.738 & $.001 *$ & .021 & 94.37 & 90.51 \\
\hline Laboratory practice $\mathrm{P} 2$ & $7.04 \pm 2.59$ & $8.12 \pm 1.72$ & 16.367 & $.000 *$ & .028 & 83.80 & 91.24 \\
\hline Final & $3.68 \pm 2.01$ & $4.52 \pm 2.14$ & 11.669 & $.001 *$ & .034 & 27.46 & 49.64 \\
\hline
\end{tabular}

ESD: Environmental Sciences Degree; $C E D$ : Chemical Engineering Degree; PI: Laboratory practice "Characterization of municipal wastewater"; $P 2$ : Laboratory practice "Settling test"; $F$ : statistic Fisher; $\eta 2$ : eta squared.

${ }^{*} p<0.05 ;{ }^{\text {a }}$ The success rate is expressed as number of students passed (grade equal or higher than 5) in relation to the number of students presented (Ballester-Sarrias et al., 2012).

Based on the grade of the exam, Table 2 shows that there were no statistically significant differences between the students of Degree in CE and the students of Degree in ES (p-value > 0.05). In this regard, the grades got by the students of Degree in CE were slightly higher than those corresponding to the students of Degree in ES, as indicated in Fig. 1 and Table 2.

In the evaluation module of monitoring, there were statistically significant differences between the students of both degrees with a p-value lower than 0.05 (Table 2). In light of this, the students of Degree in CE obtained higher grades than those belonging to Degree in ES (Table 2).

Concerning the grade obtained by the students in the laboratory practices, it should be noted that the students of the Degree in CE obtained grades significantly higher than those of the Degree in ES (7.81 \pm 2.04 vs. $7.00 \pm 2.03$ for P1, and $8.12 \pm 1.72$ vs. $7.04 \pm 2.59$ for $\mathrm{P} 2$, respectively) at a significance level of $5 \%$ (Table 2). Nevertheless, it is necessary to point out that there were no statistically significant differences in the marks of the laboratory practices carried out by the students of the same degree. This indicates that the performance in practical tasks was independent of the type of laboratory practice performed by the students.

Considering the results obtained, an important aspect to point out is the fact that the students from both degrees always obtained the higher grades in the module of laboratory practices, followed by the grades got in the modules of monitoring and exam (Figure 1 and Table 2). In light of this, it is worth mentioning that the effect size of ANOVA was of small absolute magnitude in all evaluation systems, with the exception of the monitoring that was medium $\left(\mathrm{\eta}^{2}=0.056\right)$, as observed in Table 2 (Richardson, 2011). This corroborates that the practice teaching is a tool which is advisable to introduce and encourage in the teaching methodology as the active strategies promote the learning (Lara and Rivas, 2009; Ballester-Sarrias et al., 2012; Fitt \& Heverly, 2012). Within this context, Ballester-Sarrias et al. (2012) obtained that the changes in the 
teaching-learning system mainly influence the academic performance of scientific subjects.

Table 2 also shows the success rate of the students of Degree in CE and Degree in ES in each of the three modules analyzed, as well as the final evaluation.

In this regard, other fact to highlight, which is supported by the values shown in Table 2 , is that the students corresponding to Degree in CE had a higher success rate than the students belonging to Degree in ES in all the modules evaluated. Actually, $49.64 \%$ of the students presented of Degree in CE finally passed the subject, while $27.46 \%$ got to pass the subject in Degree in ES, which approximately means the half of the students in relation to Degree in CE. Apart from scientific or academic factors, this could be due to the difference of one year in age and maturity between the students of both degrees, which is critical at this age of sharp transition from adolescence to adulthood. According to Gren \& Al-Sabbagh (2017), when the group development increases, the planning effectiveness also improves in the software engineering context. This provides evidence to support a relationship between group development and team performance. Other studies also confirm that task performance and work activity occur at higher levels later in a group's development (Buzaglo \& Wheelan, 1999; Wheelan \& Tilin, 1999). Thus, there are indications that a more mature group is possibly more effective (Gren et al., 2017).

According to the results obtained, the students of Degree in CE had a higher academic performance. It should be noted that the students of Degree in CE develop, in a more noticeable way, skills and competences concerning the design of sampling, data processing and analysis of results, using mathematical programs in several subjects of previous courses, according to the plan of study of Degree in CE (ANECA, 2000a). This could also explain most of the results obtained in this study.

\section{Conclusions}

In general, there were statistically significant differences in the academic performance shown by the students of Degree in CE and Degree in ES, obtaining the students of Degree in CE higher grades in all the modules assessed (laboratory practices, exam and monitoring). The results show that the students of Degree in CE had a success rate in the final evaluation of $49.64 \%$ in relation to $27.46 \%$ of the students belonging to Degree in ES. This trend could result from scientific or academic factors, as well as from different levels of maturity of the students as demonstrated in Developmental Psychology since there was a difference of one year in age between the students of Degree in CE and those belonging to Degree in ES.

The grades obtained by the students from both degrees in the laboratory practices were higher than those got in the modules of exam and monitoring, which proves the importance of encouraging the practice teaching as a learning strategy as EHEA recommends. 


\section{Acknowledgements}

This work was supported by the Spanish Ministry of Education, Culture and Sport under Grant FPU number AP2010-1552 awarded to J.C. Leyva-Díaz; and the Spanish Ministry of Science and Innovation under Grant FPI number BES-2011-047862 awarded to R. Álvarez-Arroyo.

The authors would like to thank their collaboration to the professors: PhD Miguel Ángel Gómez Nieto (Full Professor) and PhD José Manuel Poyatos Capilla (Associate Professor). Both professors belong to the field of Environmental Technology of the Department of Civil Engineering of the University of Granada and are the responsible professors of the subjects "Environmental Engineering" from the Degree in Chemical Engineering and "Water Treatment and Technology" from the Degree in Environmental Sciences.

\section{Funding}

The present work has not been funded by any Institution.

\section{Financiación}

El presente trabajo no ha sido financiado por ninguna Institución.

\section{References}

Aamodt, P.O., Prøitz, T.S., Hovdhaugen, E., \& Stensaker, B. (2007). Learning outcome in higher education. NIFU STEP report 40/2007, Oslo.

Aamodt, P.O., \& Hovdhaugen, E. (2008). Assessing Higher Education Learning Outcomes as a Result of Institutional and Individual Characteristics. In IMHE General Conference (pp. 1-16). NIFU STEP, Oslo.

ANECA (2000a). Plan of study. Degree: Chemical Engineering (University of Granada). Retrieved from http://vicengp.ugr.es/pages/_gradosverificados/38ingenieriaquimicaverificado/!

ANECA (2000b). Plan of study. Degree: Environmental Sciences (University of Granada). Retrieved from http://vicengp.ugr.es/pages/_gradosverificados/07cienciasambientalesverificado/!

ANECA (2005a). White Book of the Bachelor Degree in Chemical Engineering. Retrieved from http://www.aneca.es/var/media/150264/libroblanco_ingquimica_def.pdf

ANECA (2005b). White Book of the Bachelor Degree in Environmental Sciences. Retrieved from http://www.aneca.es/var/media/150340/libroblanco_ambientales_def.pdf

Ballester-Sarrias, E., Puyuelo-Cazorla, M., Contat-Rodrigo, L., Gasch-Salvador, M., \& Sánchez-Ruiz, L.M. (2012). Analizing students performance in an EHEA BEng Industrial Design Engineering degree. In Proceedings - Frontiers in Education Conference, FIE 6462530.

Bayón, L., Grau, J.M., Ruiz, M.M., Otero, J.A., \& Suárez, P.M. (2013). EEES : Nuevas actividades de Enseñanza / Aprendizaje en asignaturas de Matemáticas. In $2^{\circ}$ Congreso virtual sobre tecnología, educación y sociedad (p. 16), México. 
Bergan, S. (2007). Qualifications. Introduction to a concept. Strasbourg: Council of Europe Publishing.

Bridgstock, R. (2009). The graduate attributes we've overlooked: enhancing graduate employability through career management skills. High. Educ. Res. Dev. 28(1), $31-44$.

Buzaglo, G., \& Wheelan, S.A. (1999). Facilitating work team effectiveness case studies from Central America. Small Group Res. 30(1), 108-129.

European Ministers Responsible for Higher Education (2009). The Bologna Process 2020 - The European Higher Education Area in the new decade. In Conference of European Ministers Responsible for Higher Education (pp. 1-6), Leuven/Louvain-la-Neuve.

Fernández-Sainz, A., García-Merino, J.D., \& Urionabarrenetxea, S. (2016). Has the Bologna process been worthwhile? An analysis of the Learning Society-Adapted Outcome Index through quantile regression. Stud. High. Educ. 41, 1579-1594.

Fitt, D.X., \& Heverly, M. (2012). Classroom assessment of student competencies. Assessment Eval. High. Educ. 19, 215-224.

González, J., \& Wagenaar, R. (2008). Universities' contribution to the Bologna Process: An introduction. Universidad de Deusto.

Gren, L., \& Al-Sabbagh, K. (2017). Group Developmental Psychology and Software Development Performance. In 2017 IEEE/ACM 39th International Conference on Software Engineering Companion, ICSE-C 20177965314 (pp. 232-234), Buenos Aires, Argentina.

Gren, L., Torkar, R., \& Feldt, R. (2017). Group development and group maturity when building agile teams: A qualitative and quantitative investigation at eight large companies. J. Syst. Software 124, 104-119.

Hager, P., Gonczi, A., \& Athanasou, J. (1994). General issues about assessment of competence. Assessment Eval. High. Educ. 19(1), 3-16.

Havnes, A. (2004). Examination and learning: an activity-theoretical analysis of the relationship between assessment and educational practice. Assessment Eval. High. Educ. 29(2), 159-176.

Herrero, H., \& Algarrada, I. (2010). Is the New ECTS System Better than the Traditional One? An Application to the ECTS Pilot-project at the University Pablo de Olavide. Eur. J. Oper. Res. 204(1), 164-172.

Lara, S., \& Rivas, S. (2009). Self-regulated learning and promotion of competences in two master-level subjects, by means of assessment templates, case method, roleplaying and digital video. Educación XX1 12, 67-96.

López-Pastor, V.M., Pintor, P., Muros, \& B., Webb, G. (2013). Formative assessment strategies and their effect on student performance and on student and tutor workload: the results of research projects undertaken in preparation for greater convergence of universities in Spain within the European Higher Education Area (EHEA). J. Further High. Educ. 37(2), 163-180.

Marcerano, O.D., \& Navarro, M.L. (2007). El éxito en la universidad: una aproximación cuantílica. Revista de Economía Aplicada 15(44), 5-39. 
McClelland, D.C. (1973). Testing for competence rather than for "intelligence". Am. Psychol. 28(1), 1-14.

Ministerio de Educación y Ciencia (2007). Real Decreto 1393/2007, de 29 de octubre, por el que se establece la ordenación de las enseñanzas universitarias oficiales, 260 BOE 25 (2007). Retrieved from http://www.boe.es/boe/dias/2007/10/30/pdfs/A44037-44048.pdf

Ministros Europeos de Educación (1999). Declaración de Bolonia. Retrieved from http://www.ond.vlaanderen.be/hogeronderwijs/bologna/links/language/1999_Bolo gna_Declaration_Spanish.pdf

Molina Álvarez, A.T. (1999). Problemática actual en la enseñanza de la ingeniería: una alternativa para su solución. Ingenierías 2(3), 10-15.

Mulder, M., Gulikers, J., Biemans, H., \& Wesselink, R. (2009). The new competence concept in higher education: error or enrichment? J. Eur. Ind. Training 33(8/9), $755-770$.

Ortega Navas, M.C. (2010). Teacher's emerging competences as a demand of the European Higher Education Area. Revista Española de Educación Comparada $16,305-327$.

Richardson, J.T.E., (2011). Eta squared and partial eta squared as measures of effect size in educational research. Educ. Res. Rev. 6, 135-147.

Rico, M., Coppens, J., Ferreira, P., Sánchez, H., \& Agudo, J.A. (2013). Everything Matters: Development of Cross- Curricular Competences in Engineering Through Web 2.0 Social Objects Mercedes. In Ubiquitous and Mobile Learning in the Digital Age (pp. 139-157), New York.

Solanes Puchol, A., Núñez Núñez, R., \& Rodríguez Marín, J. (2008). Elaboración de un cuestionario para la evaluación de competencias genéricas en estudiantes universitarios. Apuntes de Psicología 26(1), 35-49.

Tembrink, T.D. (2006). Evaluación. Guía práctica para profesores, 8th ed., Narcea, Madrid.

Wheelan, S.A. \& Tilin, F. (1999). The relationship between faculty group development and school productivity. Small Group Res. 30(1), 59-81. 